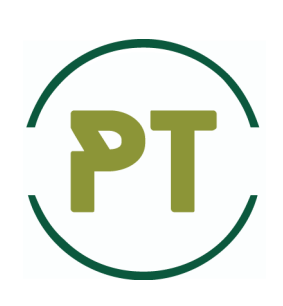

Problems of Tribology, V. 25, No 3/97-2020, 19-24

Problems of Tribology

Website: http://tribology.khnu.km.ua/index.php/ProbTrib

E-mail:tribosenator@gmail.com

DOI: https://doi.org/10.31891/2079-1372-2020-97-3-19-24

\title{
Character of formation of secondary protective structures during operation of parts in friction
}

\author{
V.M. Romanchenko \\ Kharkiv Petro Vasylenko National Technical University of Agriculture \\ E-mail: taras.maltsev@gmail.com>
}

\begin{abstract}
The structure and nature of the formation of secondary protective structures during the operation of parts in an oxidizing environment are considered. It has been established that the stability of film coatings in operation depends on the material of the main part and the development of diffusion processes with the formation of various phases and their interactions.

Based on comprehensive studies using the optical-mathematical method for the description of phases and their combinations, the development of diffusion processes during friction, the possibility of predicting the formation of more stable secondary protective films in the operation of parts to increase their operational stability is shown.
\end{abstract}

Key words: secondary protective structures, oxidizing environment, film coatings, friction, diffusion processes, operational stability.

To describe the processes of formation of secondary protective structures, which significantly increase the wear resistance of parts, preventing surface chipping during friction, reduce the sticking tendency in conjunction, we used an integrated approach in research.

It does not seem possible to evaluate the development of formation processes of the secondary protective oxide films at the phases of nanostructured coatings because of their small size, therefore, their growth and bond with the substrate were studied using model samples. As such, high-strength roll cast iron with a significant proportion of carbides (structurally free), graphite, ferrite, and matrix phase-perlite was chosen.

The set of such phases will allow to get an idea of what happens in nanostructured coatings, where zones with a matrix phase are also formed (the main strengthening metal and nanoparticles of the GrN, TiN, $\mathrm{ZrN}, \mathrm{WC}$, etc. type) when the components are segregated from the substrate. In this case, it is important to get an idea of the influence of the inhomogeneous distribution of phases, also of the droplet, which consists of the main component, including that coated with oxides.

The cast iron selected above was selected as model and is used in the metallurgical industry for rolling rolls of hot-rolled metal. During operation, they are subjected to cyclic heating and deformation of the working surface. Such a metal forming tool undergoes cyclic heating of the working surface in contact with metal rolling, intensive friction and wear, and when leaving the deformation zone it is cooled by water, as a result of which the temperature on the working surface does not exceed $600{ }^{\circ} \mathrm{C}$.

\section{Research technique}

To identify secondary protective structures formed on the friction surface, the nature of growth, the role of the phase composition of the substrate and assessment of the influence of diffusion processes on their decoration, we used a special setup [1] with a vacuum chamber, which allowed the samples to be heated to $800^{\circ} \mathrm{C}$ and observe, record the results of etching at different temperatures under the conditions of sample deformation (compression), which also made it possible to simulate the creation of local deformations.

Depending on the etching temperature, the film components (oxygen, carbon) evaporated to varying degrees, settling on the walls of the chamber. This made it possible to record the structure and nature of their growth. Then, such samples were analyzed in an electron microscope, and the phase composition of the surface was described by the optical-mathematical method described in detail in [2 - 4]. The calculations evaluated the 
composition of the phases by a predetermined interval of colors (or shades from white to black), and also determined their paired relationships.

Diffusion processes in the substrate and in the film of secondary structures studied based on the degree of heterogeneity by the optical-mathematical description of the phases and the dislocation structure.

This work involved that the calculation program by the optical-mathematical method scanning photographs with a $3 \times 3$ pixel cell. In this case, general analysis of each photograph was carried out according to the results of 600 pixels scanning. Such images were divided into 18 options and 15 intervals. They were evaluated according to different and identical colors that corresponded to the one or different phase, as well as their relationships.

\section{Research results}

Fig. 1 shows the characteristic structures of the secondary protective films after vacuum etching.

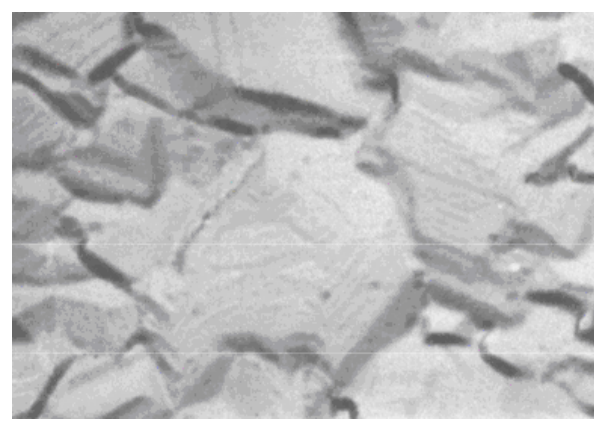

$\mathbf{a}$

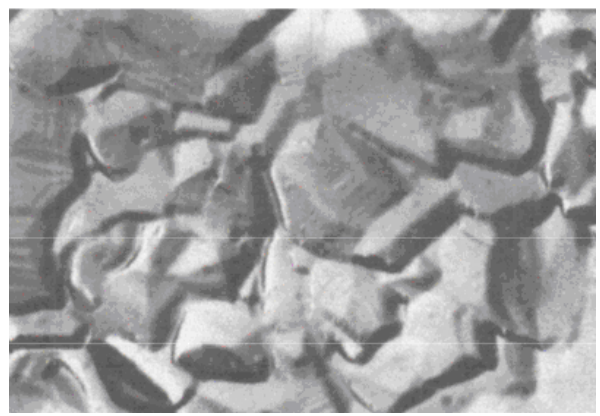

b

Fig. 1. The nature of the growth of secondary protective structures during friction in oxidizing environment, X11600

An analysis of the photographs shows that the oxide film is not monolithic and consists of individual fragments, some of which have the correct shape in the form of pyramids and stripes on their surface, which characterizes the discrete conditions for their growth. The revealed fragments of such structures can be characterized by random conditions of their growth due to different structures and defects in the substrate.

Based on previous studies, it was found that the main diffusing components during friction or the impact of deformation, including the local one, can be $\mathrm{C}, \mathrm{Fe}, \mathrm{Cr}, \mathrm{O}, \mathrm{N}$ and they can form different phases on the surface [5], which will differ from the stoichiometric composition, for example, ferrite saturated with carbon, carbides, oxides at the location of defects (dislocations) in various phase components.

Since the description of the structure formation of oxide films is a complex and unstable process associated with the diffusion of components from the substrate and the possibility of the formation of various phases and their compounds on the surface, including oxygen, we used the optical-mathematical method to describe them in color (shades).

The calculations (Table 1 and Fig. 2) revealed that only 18 options were identified, including 15 colors, of which 8 phases that are represented by the following intervals 1 by graphite (№ 3 ) 5 by bainite (№ 10), as well as carbides - cementite (№ 15) and non-stoichiometric composition (№ 11 - 14).

The interval of ferritic phases reflects a different degree of saturation with carbon due to the diffusion of this component over dislocations from the substrate.

Graphite during friction is damaged, and the proportion of carbon in it decreases significantly and cavities are formed that fill oxygen.

Carbide inclusions $\left(\mathrm{Fe}_{3} \mathrm{C}\right)$ also lose some of their carbon due to damage and an increase in dislocation density. 
Calculation of the phases formation

Table 1 and their combinations during friction, described by the optical-mathematical method

\begin{tabular}{|c|c|c|c|c|c|c|}
\hline \multicolumn{7}{|c|}{ Color combinations } \\
\hline № of variant & \multicolumn{7}{|c|}{ identified } & \multicolumn{1}{c|}{ of cases } \\
\hline 1 & 3 & 0 & 0 & 0 & 0 & 1,048 \\
\hline 2 & 7 & 0 & 0 & 0 & 0 & 1,353 \\
\hline 3 & 8 & 0 & 0 & 0 & 0 & 2,148 \\
\hline 4 & 9 & 0 & 0 & 0 & 0 & 2,339 \\
\hline 5 & 10 & 0 & 0 & 0 & 0 & 3,217 \\
\hline 6 & 11 & 0 & 0 & 0 & 0 & 6,642 \\
\hline 7 & 12 & 0 & 0 & 0 & 0 & 11,431 \\
\hline 8 & 13 & 0 & 0 & 0 & 0 & 14,8 \\
\hline 9 & 14 & 0 & 0 & 0 & 0 & 7,192 \\
\hline 10 & 15 & 0 & 0 & 0 & 0 & 1,061 \\
\hline 11 & 6 & 7 & 0 & 0 & 0 & 1,777 \\
\hline 12 & 7 & 8 & 0 & 0 & 0 & 2,516 \\
\hline 13 & 8 & 9 & 0 & 0 & 0 & 3,127 \\
\hline 14 & 9 & 10 & 0 & 0 & 0 & 3,856 \\
\hline 15 & 10 & 11 & 0 & 0 & 0 & 5,635 \\
\hline 16 & 11 & 12 & 0 & 0 & 0 & 7,399 \\
\hline 17 & 12 & 13 & 0 & 0 & 0 & 7,496 \\
\hline 18 & 13 & 14 & 0 & 0 & 0 & 4,569 \\
\hline 19 & 0 & 0 & 0 & 0 & 0 & 0 \\
\hline
\end{tabular}

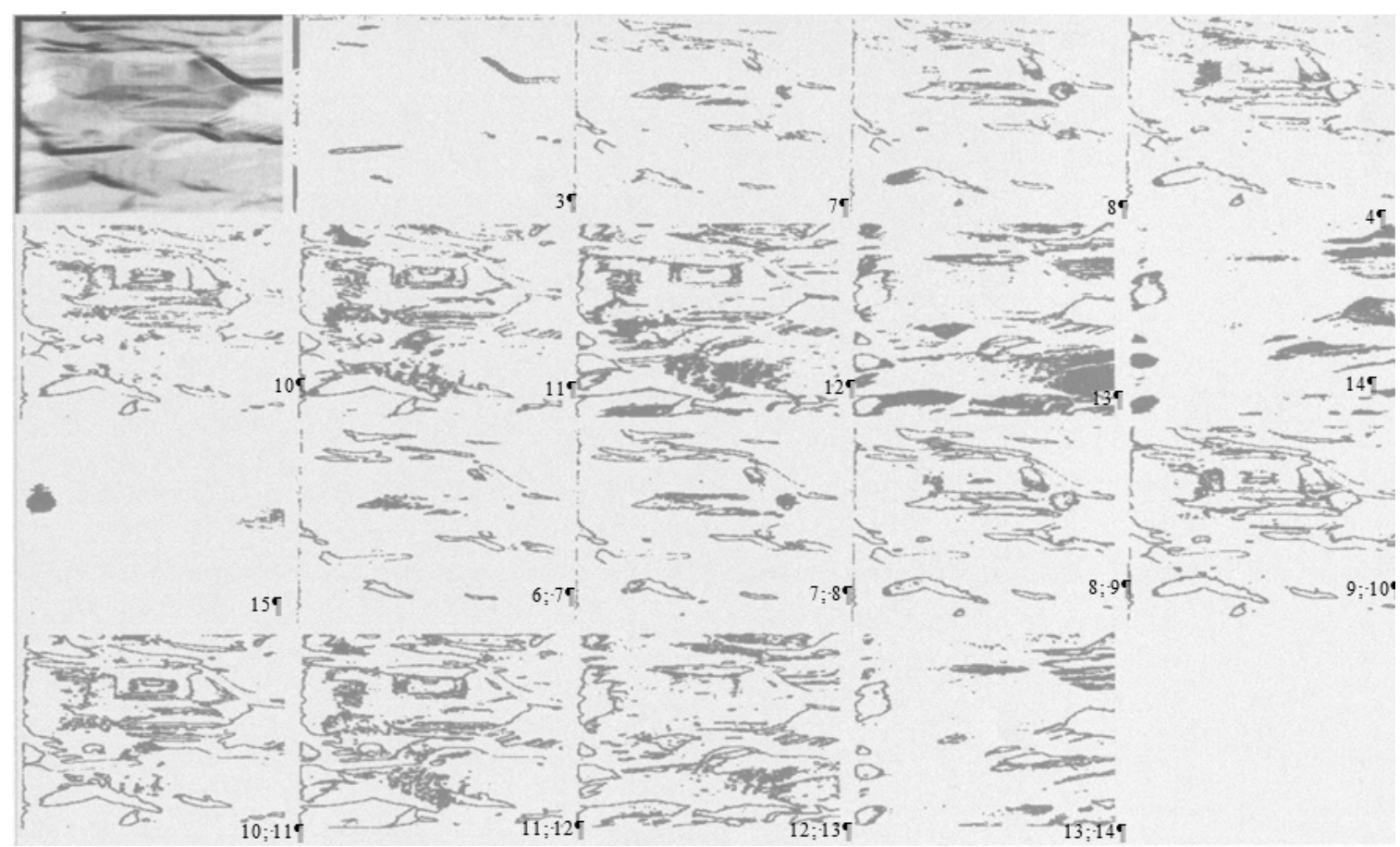

Fig. 2. The nature of the distribution of conventional colors in phases and their paired combinations on the friction surface

Based on the information obtained earlier, it was described the state of these phases during friction and wear under the conditions of operation in the oxidizing environment.

It can be assumed that ferrite components that interact with each other and with non-stoichiometric carbides (point) decorating dislocations will be especially saturated with carbon and oxygen. At the same time, such ferrite components will also form ternary compounds with iron oxides in the film. This will contribute to the formation of iron oxides $\mathrm{FeO}, \mathrm{Fe}_{2} \mathrm{O}_{3}$ and $\mathrm{Fe}_{3} \mathrm{O}_{4}$.

Since pure components that are not included in the compounds of film coatings (carbon, oxygen) evaporated during vacuum etching of the investigated surfaces, their share was not taken into account. The working surface was subjected to analysis by newly formed types of phases and their pairwise interactions. 
Based on the calculations, it was found that the maximum fraction in the film is made up of single phases that reaches $51.23 \%$. Judging by the photographs described, such phases are stood out both in places of damage to the film, and when decorating the spirals of its growth. Moreover, the fraction of ferritic components of varying degrees of carbon saturation is almost two times greater than bainite 6.89 and $3.22 \%$, respectively.

In such zones, single phases and non-stoichiometric carbides in a significant amount up to $-40.97 \%$ were revealed, while cementite did not exceed $1.06 \%$.

Paired interactions with each other form ferrite phases, including the ferrite phase with lower carbon content № 6, but the most highly saturated carbon № 9 is interconnected with bainite № 10. At the same time, bainite is interconnected with non-stoichiometric $\mathrm{FeC}$ carbide (№ 11). The remaining types of nonstoichiometric carbides are interconnected (up to $19.46 \%$ ), and $\mathrm{Fe}_{3} \mathrm{C}$ is absent.

The obtained calculation results and the optical-mathematical description of the structure give a complete picture of the instability of the phases formed in the secondary protective films during friction and allow to imagine the degradation processes in the working metal layer during friction and wear.

Since it was established from the performed studies that the main components that diffuse from the base metal into film coatings on the friction surface are carbon and iron, we carried out special studies regarding the development of structural changes under stress.

An analysis of the research results showed that the degree of diffusion of the components (Fig. 3 and Table 2) is determined by the number of defects, their slip and interaction. The dislocation structure was also described by the optical-mathematical method.

Table 2

\section{Calculation of the formed phases and their combinations at local deformation, estimated by the optical-mathematical method}

\begin{tabular}{|c|c|c|c|c|c|c|}
\hline \multicolumn{7}{|c|}{ Color combinations } \\
\hline № of variant & \multicolumn{7}{|c|}{ № of variant } & № of variant \\
\hline 1 & 13 & 0 & 0 & 0 & 0 & 1,828 \\
\hline 2 & 14 & 0 & 0 & 0 & 0 & 3,252 \\
\hline 3 & 6 & 7 & 0 & 0 & 0 & 1,509 \\
\hline 4 & 7 & 8 & 0 & 0 & 0 & 2,018 \\
\hline 5 & 8 & 9 & 0 & 0 & 0 & 1,575 \\
\hline 6 & 9 & 10 & 0 & 0 & 0 & 1,739 \\
\hline 7 & 10 & 11 & 0 & 0 & 0 & 2,678 \\
\hline 8 & 11 & 12 & 0 & 0 & 0 & 5,566 \\
\hline 9 & 12 & 13 & 0 & 0 & 0 & 13,375 \\
\hline 10 & 13 & 14 & 0 & 0 & 0 & 22,844 \\
\hline 11 & 14 & 15 & 0 & 0 & 0 & 20,466 \\
\hline 12 & 7 & 8 & 9 & 0 & 0 & 1,032 \\
\hline 13 & 8 & 9 & 10 & 0 & 0 & 1,187 \\
\hline 14 & 9 & 10 & 11 & 0 & 0 & 1,45 \\
\hline 15 & 10 & 11 & 12 & 0 & 0 & 1,976 \\
\hline 16 & 11 & 12 & 13 & 0 & 0 & 3,117 \\
\hline 17 & 12 & 13 & 14 & 0 & 0 & 4,267 \\
\hline 18 & 13 & 14 & 15 & 0 & 0 & 3,042 \\
\hline
\end{tabular}

It has been shown that there are no single cementite inclusions at the place of their defects location and instead separate carbides of non-stoichiometric composition like $\mathrm{Fe}_{\mathrm{x}} \mathrm{C}_{\mathrm{y}}(5.08 \%)$ are detected. Ferritic phases with varying degrees of carbon saturation are detected in paired and triple relationships.

Moreover, the largest proportion is characteristic of double bonds of carbide phases of non-stoichiometric composition and cementite, corresponding to numbers № $11-12$; № 12 - 13; № 13 - 14; № 14 - 15 (a total of $62.24 \%$ ). This confirms the great instability of cementite and its decomposition not only into non-stoichiometric carbides, but also to the appearance of ferrite and bainite at the place of detection of the dislocation structure.

Relatively triple interactions, they mainly relate to the decomposition of cementite and to a lower extent relate to the saturation of ferrite with carbon. However, its decay contributes to an increase of bainite (№ 9 in combinations 9 - 11 and $10-12$ ). 


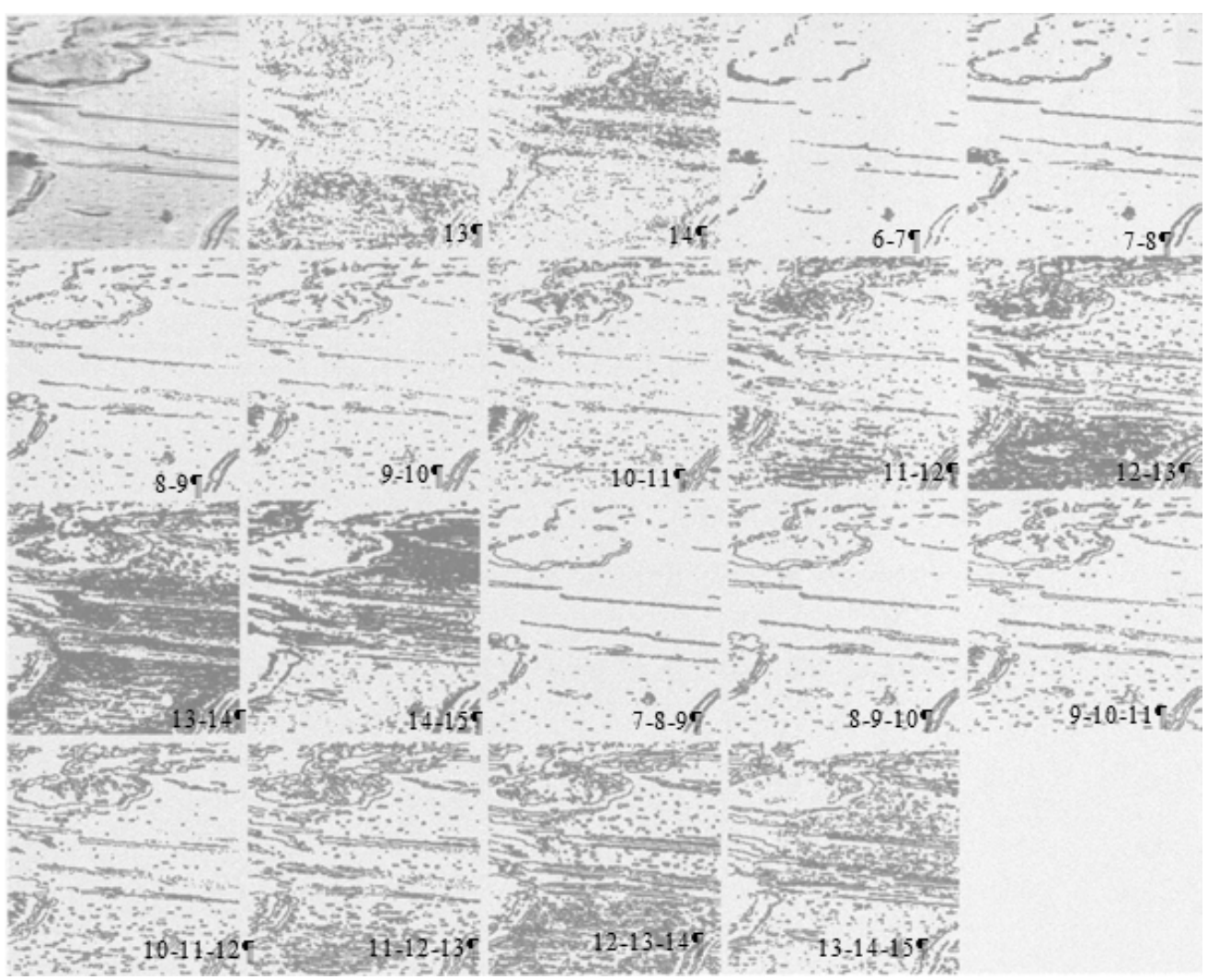

Fig. 3. The nature of the phases distribution that decorating the dislocation structure

From the information obtained, it is clearly seen that the main diffusing component in the film coating is carbon and, to a loser extent - iron. Therefore, the proportion of carbon-containing phases is significantly large.

To determine the closest and most stable phase of the secondary protective structures, which, in the presence of oxygen in the friction center, form a more stable structure with growth spirals, zones of their formation were digitized by the optical-mathematical method and various phases were revealed. It was found that film growth in spirals is characteristic of zones with a sublayer, which is characterized by a more uniform structure. In this case, this is a ferritic phase with dispersed carbides of non-stoichiometric composition with a cubic crystal lattice, and $\mathrm{F}_{\mathrm{e}} \mathrm{O}, \mathrm{Fe}_{2} \mathrm{O}_{3}$, and $\mathrm{Fe}_{3} \mathrm{O}_{4}$ oxides [6], which are part of secondary protective structures, have the same structure. Fig. 4 shows the compared structure after digitization.

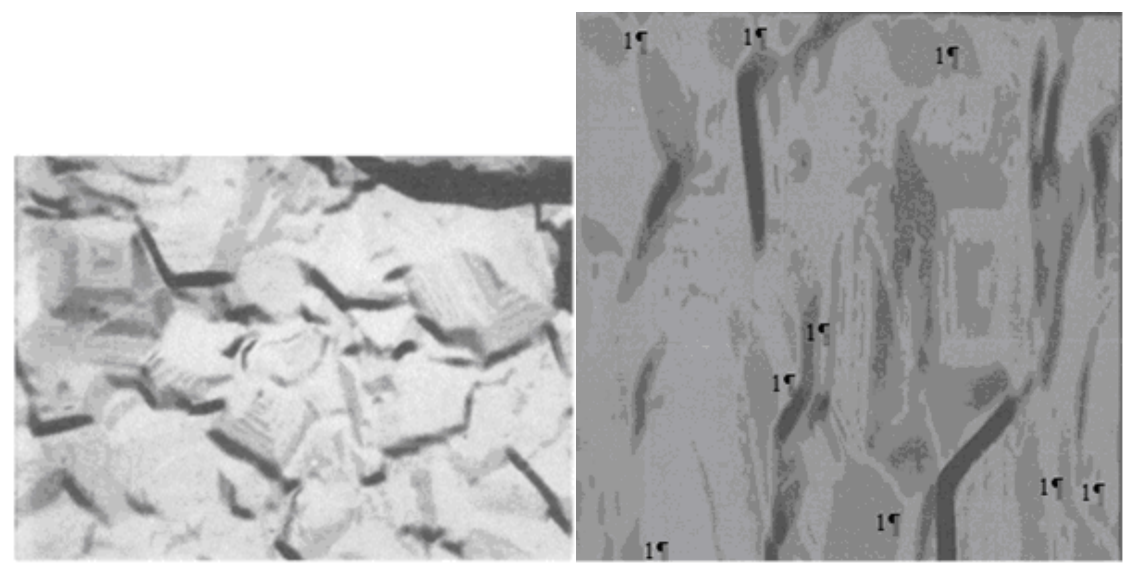

Fig. 4. Comparative phase composition in color of formation areas of secondary protective structures with growth spirals (indicated by the number 1 - blue color) and without them

From the information obtained on the comprehensive studies, it can be concluded that, regardless of the type of restorative coating for the formation of more stable protective film oxide structures, it can be achieved in the presence of phases in the substrate with the same crystal lattice type. Such a coating should contain components that during operation will diffuse onto the friction surface, forming new phases and slow down the tendency of the friction surface to completely destroy the protective structures during each test cycle. 
Based on the studies performed, recommendations can also be effective for improving the operational stability of parts hardened by nanostructured coatings, which will provide oxygen to the friction center and will increase their resistance based on prediction of compositions that take into account the material of the part being processed.

\section{References}

1. Prokatnye valki iz vysokouglerodistyh splavov. T. S. Skoblo, I. M. Voroncov, S. I. Rudyuk. Iz-vo «Metallurgiya» M. 1994, 336 s.

2. Appoaches in Stuly of Inhomoqeneity of Heteroqeus Structures. T. C. Skoblo, O. Y. Klochko. E. Y. Belkin. A. I. Sidashenko. Metallofiz. Voreishit Fechnoloq. (W4a), 2, 2018, p 255-280.

3. Teoreticheskie i eksperimentalnye osnovy prognozirovaniya strukturoobrazovaniya svojstv vysokouglerodistyh legirovannyh splavov. Monografiya. T. S. Skoblo, I. Yu. Klochko, A. I. Sidashenko, E. L. Belkin. H.: Disa plyus. 2019. 278 s.

4. Optiko-matematicheskij analiz modelirovaniya strukturizacii uprochnennyh poverhnostej porshnevyh koles pri ekspluatacii. T. S. Skoblo, A. I. Sidashenko, I. E. Garkusha i dr. Metallofizika i novejshie tehnologii 2019 № 3, S. 345-362.

5. Korpusni detali z chavuniv ta yih yakisni pokazniki. T. S. Skoblo, O. I. Sidashenko, O. V. Sajchuk. H.: Disa plyus, 2019. $282 \mathrm{~s}$.

6. Narita K. Kristallicheskaya struktura nemetallicheskih vklyuchenij v stali. Iz-vo «Metalurgiya», M. 1969. $196 \mathrm{~s}$

Романченко В.Н. Характер образования вторичных защитных структур при работе деталей при трении.

Рассмотрено строение и характер формирования вторичных защитных структур при эксплуатации деталей в условиях окислительной среды. Установлено, что стабильность пленочных покрытий в эксплуатации зависит от материала основной детали и развития диффузионных процессов с формированием различных фаз и их взаимодействий.

На основе комплексных исследований с использованием оптико-математического метода описания фаз и их сочетаний, развития диффузионных процессов при трении показана возможность прогнозирования формирования более стабильных вторичных защитных пленок в эксплуатации деталей для повышения их эксплуатационной стойкости.

Ключевые слова: вторичные защитные конструкции, окислительная среда, пленочные покрытия, трение, диффузионные процессы, стабильность работы. 